\title{
Belgeo
}

Revue belge de géographie

$4 \mid 2019$

Les politiques de mobilité urbaine en Europe après la crise : adaptations et innovations

\section{Bike mobilities, democratic revival and the local fix}

Valencia, from corruption epicentre to Mediterranean cycle capital

\section{Nacima Baron}

\section{(2) OpenEdition}

\section{Journals}

Electronic version

URL: http://journals.openedition.org/belgeo/36436

DOI: 10.4000/belgeo.36436

ISSN: 2294-9135

Publisher:

National Committee of Geography of Belgium, Société Royale Belge de Géographie

\section{Electronic reference}

Nacima Baron, «Bike mobilities, democratic revival and the local fix », Belgeo [Online], 4 | 2019, Online since 09 February 2020, connection on 20 July 2020. URL : http://journals.openedition.org/belgeo/ 36436 ; DOI : https://doi.org/10.4000/belgeo.36436

This text was automatically generated on 20 July 2020 .

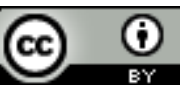

Belgeo est mis à disposition selon les termes de la licence Creative Commons Attribution 4.0 International. 


\title{
Bike mobilities, democratic revival and the local fix
}

\author{
Valencia, from corruption epicentre to Mediterranean cycle capital
}

\author{
Nacima Baron
}

This study is part of a multiannual research programme funded by the Institut des Hautes Etudes Hispaniques et Ibériques - Casa de Velazquez «Métropoles espagnoles, crises et mutations».

It follows on directly from a conference held on $30^{\text {th }}$ May 2018 at Valencia University and a visit to the Municipality. Some aspects of this event have been published under the title "Territorial culture and social innovation: towards a new metropolitan model in Southern Europe?" (see references).

It was also undertaken following a guest programme funded by Université Paris Est and awarded to Juan Miguel Albertos Puebla in June and July 2018. The author would like to thank all the institutions mentioned, and in particular Professor Albertos Puebla for his scientific collaboration.

\section{Introduction}

1 In the studies that chronicle the 2008 crisis in Spain, Valencia is the epicentre of real estate overproduction supported by a corrupt local government (Pueyo, Hernandez, 2013). Ten years on, Spain's third biggest city ${ }^{1}$ conveys an image of peaceful recovery (Medina, 2018). The current municipal team boasts of the emergence of a cycling paradise, aided by the sunny climate, the flat topography and the relative compactness of the city centre. This turnaround is not unprecedented, but Valencia provides an ideal vantage point for a critical study of the role of sustainable mobilities and especially cycling in broader democratic change, because it helps to link two transformations.

2 The first transformation is related to politics. An important event took place in Spain in 2015. The historical two-party system (PSOE and PP) was eroded. In a dozen municipalities, new parties, partially originating in civil society and related to the 2011 
Indignados movement (born in Puerta del sol), emerged and took power in Madrid, Barcelona, Cadiz.... Calling themselves the "Municipalities of change", these local authorities advocate a democratic renaissance (Romero et al., 2018). Valencia can also be identified with this trend, but with a local specificity. The mayor elected in 2015 (comfortably re-elected in 2019, which is not the case for all the other municipalities of change) belongs to Coalició Compromís, which includes a leftist ecological party (Verds Equo), a social democratic regionalist party (Compromís, which exists only in the Valencia region) and the socialist party.

3 The second transformation in progress is the long-term path to sustainability, especially in urban mobility and transport. It is well known that a majority of Mediterranean cities are strongly marked by the "car system" (Urry, 2004) and are somewhat behind in terms of the transition to green mobilities compared with northwest Europe (Héran, 2014). Yet Valencia's mobility system is changing rapidly. The 2015-2019 municipality made a genuine effort in the sphere of public infrastructure and public space. Although cycling was not a widespread practice in the city, now 40 kilometres of protected two-way cycling lanes have been built and cycle use is on the rise. This shows that the municipality was proactive in its political approach, seeking to initiate a change in the mobility system despite tough constraints.

4 This article examines the intersection of both transformations and explores the way cycling has been introduced and legitimised in the local agenda. Recognising the fact that the municipality systematically casts pro-cycling measures as related to democracy, the research explores the connection between mobility reform and democratic revival.

5 The main hypothesis is that change associated with mobilities occurs not only in space, but through space. Here, space is not only physical (the spatiality of the city) but also representational and embodied. That is why a mixed methodology has been employed in order to grasp, on the one hand, the materiality of urban change and the transformation of local practices associated with bike policies, and on the other hand the discursive and performative component of bike politics. In the first methodological approach, the article applies two notions - tactical urbanism and political framing - in order to understand how the municipal team, as soon as it won power, captured and occupied public space through performative uses of the bicycle (Part 1). In the second part, the article studies the production of a discursive space that links together the expression of concrete planning operations, the propagation of behavioural principles and the affirmation of values and core political beliefs (Part 2). Here, it shows that political change is rooted and made visible in pro-bike discourses. The author analyses the "storyline" of Valencia's mobility policy and employs innovative semantic and argumentative heuristics to map pro-bike public discourse and interpret it as political drama. This leads into a final section which explains the effectiveness of such a strategy and, in a broader approach, discusses the links between sustainable mobility policies and postcrisis urban image repair in Mediterranean cities. 


\section{Setting the agenda for sustainable mobilities}

\section{Political framing and urban narrative}

6 Political framing refers to the way in which political actors interpret actions, give them meaning and make them a basis for negotiated collective action (Hassenteufel, 2010). Following the success of the "municipalities of change" in the local elections of May 2015 (Lopez 2015), sustainable mobilities have come onto the political agenda in various ways. The issue emerged after the economic crisis, in a context of rising environmental awareness and at a moment of shift in the political landscape. In most Spanish cities, the car significantly dominated the local mobility system, a factor that had become a social problem at this time, connected with this political shift (Boix et al., 2015). The bicycle, in particular, offered a solution in that it conditioned the terms of the debates, the method of handling them and any ultimate decisions. In Madrid, support for the bicycle was a response to the issue of air pollution. In Barcelona, the municipality tried in vain to finalise a tramline project, and then, unable to do so, overcame this political blockage by an ambitious cycle lane construction programme. In Valencia, a cycle plan had been in place since 2013, under the former rightist municipality, but cycling policy embarked on a very new "political career" (Garraud, 2010) with the seismic shift of 2015. This date marked the collapse of the (rightist) Popular Party that had run the municipality for 24 years and the autonomous community for 21 years. The newly elected representatives joined a center-left coalition (Coalició Compromís) that wanted to clean up a landscape polluted by politico-financial scandals. Any action concerning movement and behaviour in public space was thus connected with (and the first step to) a broader reform of political conduct (Abellan and Pardo, 2017). In a city where almost all the former city councillors were in prison, the incoming team continuously linked the old system, depicted as the "dictatorship of the car", with the former model of governance. In contrast, a friendly city - "Ciudad amable" - model linked sustainable mobilities, morality in public life and environmental amenities. This model is described as follows: "Neighbourhoods that are lively and dynamic, but at the same time quiet and attractive, clean streets, preferably pedestrianised, good shopping amenities and respectful tourism"' (Grezzi 2016).

7 A literature review will help us to conceptualise the political turning point in Valencia and offer significant insights into the local conditions of implementation of cycling policies with respect to political attitudes, symbols and values. In an inspiring monography dedicated to Munich, Chelsea Tschoerner Budde argues that the bike plays an essential role in "reproducing and transforming a political discursive order" (2017, p. 66). She refers to the linguist Hajer (1995) and to the linguistic concept of the storyline. The purpose of the storyline is to change the narrative, i.e. to bring about a change in the social understanding of an issue (here mobility and public space). It accompanies the intention to construct or renovate a local community identity.

The friendly city model cited here can be seen as an alternative Valencian storyline designed to sustain a political discourse about cycling and its benefits: a mode of transport that is cheap, efficient, environmentally friendly, a healthy form of exercise, a means of freedom and escape. To advance this storyline, cycling, urban model and governance model are interwoven in municipal visuals and texts around the concept of the Ciudad amable. In this story, sustainable mobilities are present as a setting and 
function (streets, traffic arteries) and as a factor of civility (the pedestrian street, an instrument of direct interaction between individuals who intermix and form a community). It manipulates symbols and "the symbolic appears not as a simple expression or a more or less illusory effect of the local political "reality", but rather as a dimension which creates this reality, which justifies the necessity of power and helps to make it acceptable" (Garraud, 2010, p. 20). This narrative reshapes and assembles different arguments on urban sustainability that travel from one city to another (Kennedy, 2016). It offers a classic example of the transnational circulation of models of sustainable urbanism (McCann and Ward, 2012). This narrative brings together other narratives (Savage, 2019) and rearranges the global with the local: some themes are specific to the Valencian storyline, in particular social organicism and an imagined territoriality: the revindication of centrality in the Mediterranean (Boira, 2003). Above all, this narrative fits with a succession of arguments that offer both a disruption and continuity of meanings.

\section{Mobilities as urban catharsis}

9 Medellín was perceived as the capital of cocaine and then emerged as a model city after the construction of a cable car that broke the isolation of the slums (Tubb, 2014). This storyline was all over the media and inspired critical ideas about the role of infrastructures in political communication in Latin America (Arenivar, 2014). In Europe, Valencia offers another case, except that here the "political fetish" (Diaz et al. 2017) is not an urban cable car, but the bicycle. The media discourse on Valencia links mobility with a metamorphosis, and the new municipal team with a catharsis, in other words a purification and sublimation of collective drives.

Recent history helps us to understand the nature of the trauma experienced by Valencia. In Valencia's images and imaginaries, a former narrative was central: the city recently underwent a transition from splendour to decline. The city emerged as a tourist destination in the 2000s thanks to a number of iconic features: a Museum of Arts and Sciences designed by "starchitect" Calatrava (Santamarina 2014), a sumptuous marina (Veses, 2016), a Formula 1 circuit (Linheira et al. 2018). Mirroring Barcelona's success story, Valencia's mayor applied global models at local level, in a classic attempt at urban branding and upscaling (Prytherch, 2003; Tarazona, 2015). This neoliberal turn (Romero et al., 2015) went hand-in-hand with a governance system called "entrepreneurial municipalism", based on the closeness between the PP and the financial and property sectors (Prytherch and Huntoon, 2005). Mega-events (visit by the Pope in 2006, Americas Cup in 2007) provided opportunities for opaque financial operations that reeked of fraud and deception. ${ }^{3}$

11 The crisis led to the breakup of the clientelist system (Cuco 2013) and plunged the city into a downward spiral. Rafael Chirbès, as a novelist, was the best anatomist of the deterioration of social relations and public values (Chirbès 2009). During the debt crisis (2011-2012), thanks to the spectacular court cases against Valencian officials, wellknown rating agencies that speculated on local authorities strangled by the crisis were not slow to come up with a "storyline, that is to say an argumentative practice which affects and shapes policies and plays a tacit role in producing political discourses" (Tschoerner Budde, 2017). Valencia became the emblem of the aberrations that caused 
the bursting of the property bubble, the epicentre of the waste of public funds, of corruption, of impunity (Baron 2014, Sorribes 2015, Romero et al., 2018 a).

This detour helps us to understand the context of moral crusade in which the 2015 local election took place. The electorate was driven by a desire for collective rehabilitation after the collapse of a dream of greatness (Santamarina \& Moncusi 2013). The new municipality wanted to replace Valencia's image as a symbol of violent and depraved governance with the soothing image of a peaceful community. The task of making this rebirth tangible was assigned, primarily and in the inner city, to sustainable mobilities and secondarily and in the outskirts, to sustainable food policy through the protection of the huerta.

\section{How sustainable mobilities embody a political change in urban space}

\section{A target: the hypercentre; a method: tactical urbanism}

Tactical urbanism consists in acting quickly and focusing on operations that are visually striking, low-cost and evolving (Mould, 2014; Lyndon Garcia, 2015). The idea is that the initial operations prompt people to begin changing their habits, so that they are won over to the benefits of a new mobility model before the next elections. The sustainable mobility representative explicitly followed this method and three shock measures were implemented in the first months after election. Traffic speed in the old centre was limited to $30 \mathrm{~km} / \mathrm{h}$, then in places to $20 \mathrm{~km} / \mathrm{h}$. The streets surrounding the market and the Lonja de la Seda (a $15^{\text {th }}$-century UNESCO registered monument) were pedestrianised in a single night ${ }^{4}$. A separate cycle lane was built on the boulevards surrounding the old centre. Subsequently, the municipality announced the redesign of the central square and, to get people used to the change, closed it to motorised traffic as often as possible. It was only in the third year of its term that the municipality undertook operations outside the city centre. It installed traffic lights to slow down traffic on two radial avenues and refurbished a few squares and parks in some peripheral neighbourhoods (Patraix, Natzaret, fig. 1). The measures implemented at metropolitan scale were even more limited. After considerable difficulties, an intermunicipal mobility authority was established and a planning document developed (PMOME Mobility plan for the Valencia Metropolitan Area, 2018). The municipal bus network had a few lines rerouted in order to reconnect peripheral communities (headed by socialist mayors) whose links to the centre had been cut off by the previous PP regime. 
Figure 1. Territorial targets and scales of sustainable mobility policies in Valencia 2015-2019.

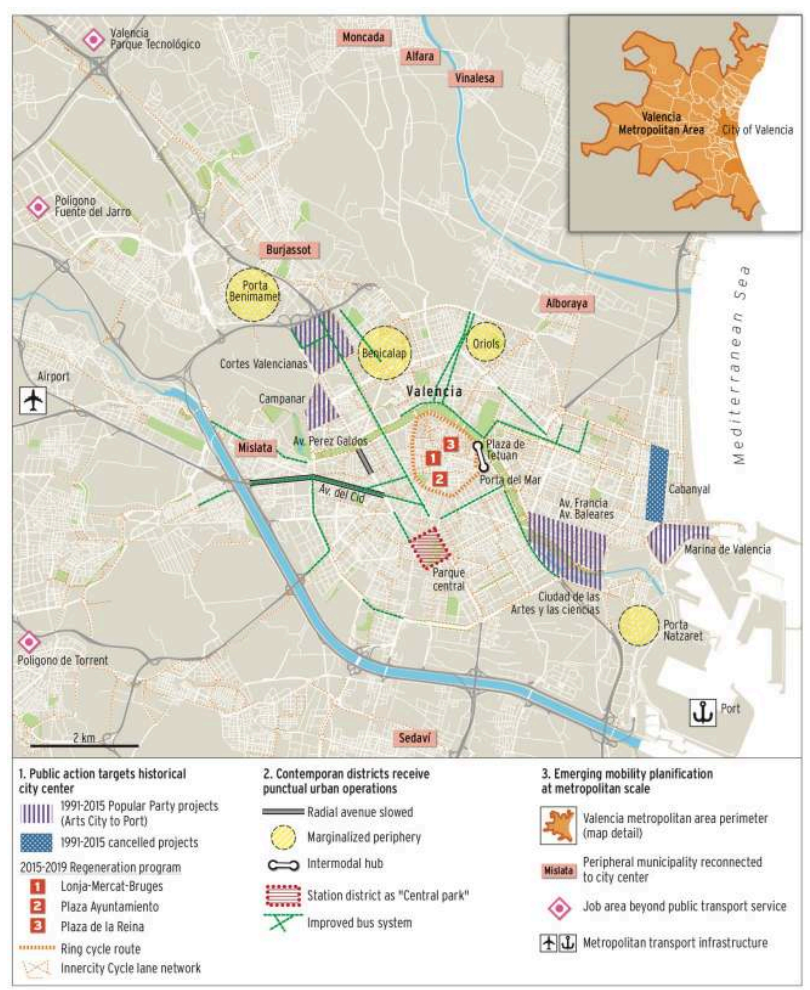

\section{Occupation of Townhall plaza, staging of sustainable mobilities}

The implementation of tactical urbanism in Valencia reveals three types of local political change. There is an alteration in the nature of urban planning projects: the big projects of the 2000s are replaced by lightweight, targeted and agile interventions on public space. Then there is a shift in the spatial targets of public action: the previous municipality had concentrated its projects at the connection between city and port, whereas the new team concentrated on the historic city centre (Fernández, 2000). And finally, there is a reoccupation of the public space released by the car. While the previous urban authorities were obsessed with monumentality and produced architectural voids (Esteban and Sorribes, 2016), density and intensity are now important goals: the new city fathers are refilling streets and squares with practices that they would like to see develop, which combine mobility and festivity. "Valencia is a party. A party for all. A party that is shared, for the people, open. Like the city we dream of and is beginning to be a reality" ${ }^{\text {" T }}$ The official calendar is packed with traditional events (such as Fallas) and cycle or sustainable mobility events (sustainable mobility week in September, cycle sprint, etc.) that fill public space with cyclists and pedestrians and convey an image of car-free places of peace and enjoyment (figure 2). 
Figure 2.The vibrant Mediterranean crowd is invited to reconquest the Valencian public space.

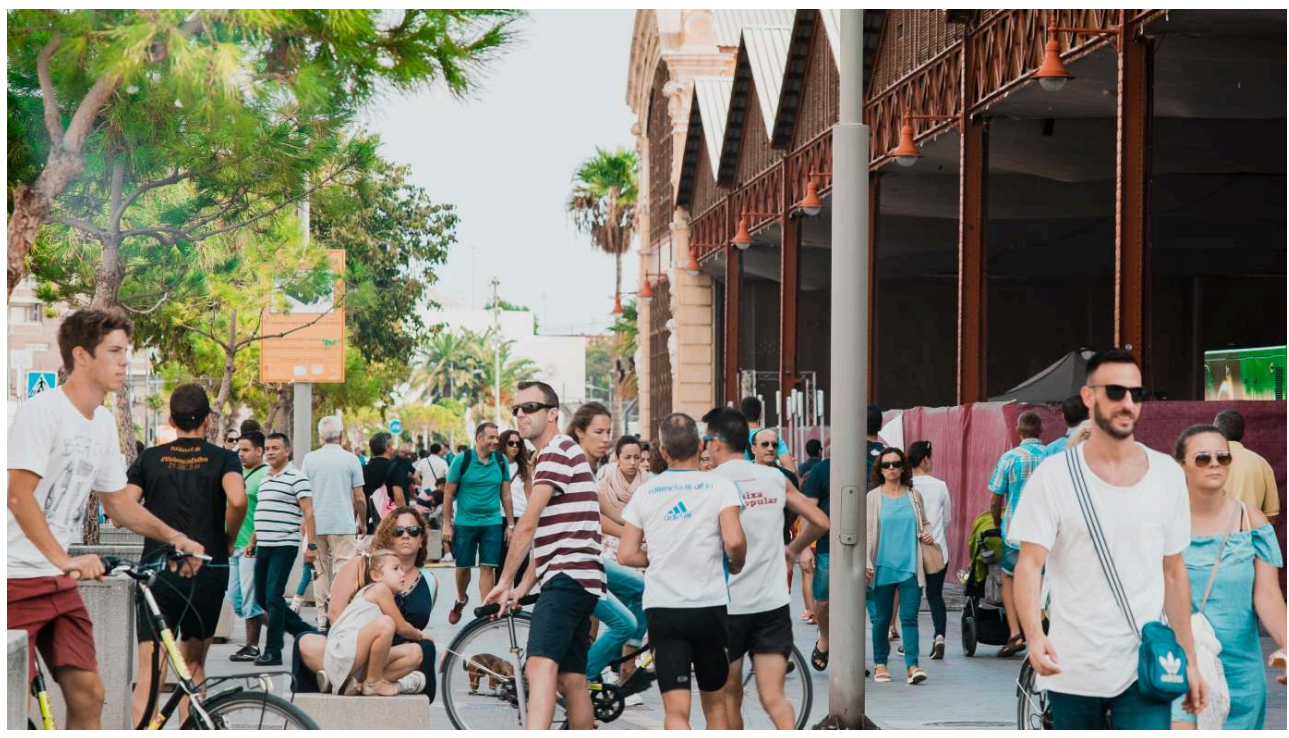

This offers the mayor and his deputies a series of political resources. Such events give politicians, individually and collectively, an opportunity to appear on the public stage on their bicycles (Milani and Duarte, 2013). Festive events are signals addressed to neighbourhood groups and associations that support the existing municipal team (such as Conbici). Moreover, cycling events are an opportunity to bring together different segments of the local population and to prepare communities to dip into new and previously unfamiliar mobility practices: this is the logic behind the introduction of cycling lessons and other educational activities. Participants are invited to reshape public space through the body in motion and to perform the bicycle. In addition, the bicycle's occupancy of the streets sets physical limits and therefore regulates other forms of mobility, such as scooters, segways and hoverboards, which are proliferating exponentially in a city that attracts huge numbers of Erasmus students and international tourists.

\section{Sustainable mobilities and political communication: spatialising a local controversy}

\section{Political communication shapes a discursive space}

Recent research has developed approaches that link linguistics, political communication in the internet age and bike mobility advocacy. Among them, Patrick Kiernan (2018) offers an innovative methodology. He analyses how politicians achieve or obtain public status by means of semiotic resources associated with the bicycle and gain an increased presence in the virtual sphere, and hence access to a broader audience. His argument is that political actors use discourse to produce, reproduce and transform socially shared understandings and to (re)shape individual and collective identity. He gives numerous examples of politicians who evoke and invoke cycling through social media and create a community of practice in virtual space. This is very helpful in conceptualising the rhetorical strategies employed by the new municipality 
to reshape the city's identity after its recent economic and political crisis and to create a Valencian (and supposedly Mediterranean) bicycle identity.

The use of social media as a political battlefield has a history. From 2008 to 2015, Valencia PP's scandals created an international, national and local virtual media arena (Lluch, 2014). Moreover, a good part of the 2015 campaign took place in and on social media (Fenoll, 2015). Leftist movements in particular used Twitter as an instrument of dialogue, maintaining a dense relational network and winning over different communities and associations, among them the green party, grassroots movements and probike groups (Velazco, 2016). Since it took power in 2015, the municipal team has maintained the information battle and pursued a "truth crusade", seeing itself as a bulwark against two dangers: the return of the old PP and the rise of populism. "Local governments are able and keen to play a central role in the struggle against far right ideas: the manipulation of information, the exploitation of inequalities and the construction of an exclusionary identity ${ }^{6}$. The municipal team developed a three-step logic for the revival and consolidation of democracy, which can be summed up as follows:

18 1. Traffic calming and the development of green modes are the path to a new city model;

2. The urban model redefines the rights and duties of citizens, in the sense that all users of public space are invited to develop mutual respect and consideration (Prytherch and Daly, 2014);

3. Once this ethical position is internalised, the whole community is protected from a return to the mafioso system that caused the city's collapse 10 years before.

Thus, by contrast with the French case where a Foucauldian governance of conduct is associated with smart mobility buzzwords and a consequent depoliticisation of discourse (Reignier, 2016), Valencia illustrates a moralisation and politicisation of mobility discourses. Twitter propagates a set of terms, ideas and symbols that shape a discursive political space which needs to be explored with the tools of discourse analysis.

Figure 3 shows this discursive space and the internal logic of the argumentative strategy. It enables us to understand the rhetorical and semiotic strategy employed by a Valencian councillor to initiate the audience into the culture of cycling and more broadly into the paradigms of sustainable mobility, while at the same time bringing immersing the reader in morality and politics. The method used to develop this graphic was Twitter datamining and qualitative discourse analysis (found in Twitter Logitech and advanced research tools). The analysis used the entire corpus of original tweets posted by the municipal councillor responsible for sustainable mobilities between May 2015 and March 2019 (i.e. 95\% of the full term, with the next elections scheduled for May 2019), the author having followed the thread over this complete period.

21 It is not the purpose of this research to compete with certain Humanum (Digital Humanities) linguistic analyses of political discourse (e.g. Longhi 2016). We consider that the argument can be demonstrated from the output of a single tweeter, because the volume of tweets is sufficient and because the aim is not to map public opinion, but only to explore the argumentative strategy of a politician whose characteristics make the study relevant. Giuseppe Grezzi, Municipal Councillor in charge of sustainable mobilities, is a big Twitter user (more than 3500 tweets and retweets in 4 years), is highly charismatic (his thread has 10,000 followers) and untypical in his profile. An Italian national in his forties, he comes from the Communist left, is a spokesman for the 
regional Verds Equo party, has a diverse educational and professional background in engineering, services and farming, and has travelled widely (this is very important, as we will see later) (see figure 2).

To ensure the quality of the materials, the tweets were extracted and stored at the time of their production, not later, since a synchronous approach is more reliable than retrospective collection. The choice of processing software was complicated by the multilingual nature of the material. The councillor expresses himself in Valencian, Spanish, English and occasionally Italian. The messages in Valencian were therefore initially translated into Spanish by a local academic. Nvivo, with its different dictionaries, provided technical support for scanning and encoding this material. The results of the discourse analysis are presented in two stages. In a first phase, quantitative analytics are provided on geographical places and cities mentioned by Grezzi. This helps us understand how the municipal councillor highlights Valencia's bike identity while connecting the local cycling community to a world cycling community (imaginary or real). In the second phase, the discursive registers are classified in order to explore the argumentative strategy and reveal the connections between different linguistic figures and arguments - statements, explanations, chronicles and narratives... - and their interplay with emotional, aesthetic, political and moral positionings.

\section{Result 1. Putting Valencia back on the map: connecting mobilities and relationalities}

According to urban geography, political stakeholders express "spatiality regimes" through which the local enters into relations with the global. On this point, a first result emerges from the lexical search: Grezzi sprinkles his utterances with names (and photos) of Copenhagen, Amsterdam, New York (see figure 3)... Such cities illustrate good cycling practice, cycle-friendly street design... They are presented as models to follow and as inter-urban leagues of good partners and friends to connect with. This finding confirms the link between relationality and territoriality that underpins the strategies of political persuasion (Temenos and McCannn, 2012). It also corroborates a key aspect of policy boosterism, i.e. the combination of identity celebration (the bike festivals and cycle days held in Valencia's townhall plaza) and the "extrospective" approach of city networking (McCann, 2013). Figure 3 is therefore a kind of fantasised representation of Valencia's idealised city network, and the topology is not, of course, necessarly Euclidean: the font size is proportional to the number of occurrences. A first circle encompasses well known cycling or walking friendly cities in Spain (Seville, Pontevedra, San Sebastian, Vitoria, Ibiza). A second circle organises places in NorthWestern Europe and the United States (Copenhagen, Amsterdam, London, Paris, Utrecht, New York, cities that Grezzi knows personally). A Nvivo textual proximity tool (which measures the textual proximity between these city names and other words) is useful in determining the councillor's intentions. These words are "urban design", "urban quality", "event", "pride", "solidarity", "model", "conference" ... He mentions foreign cities in connection with an official event in Valencia or when he is invited abroad to talk about Valencia's metamorphosis and catharsis. He emphasises the sponsorship he receives from the network but, from 2017 on, begins to talk about Valencia as a model for other Mediterranean cities. He also explains that he has met 
experts in good mobility practices in situ and divulges good mobility standards and practices.

Figure 3. City names cited by Valencia Deputy to foster change in mobility model.

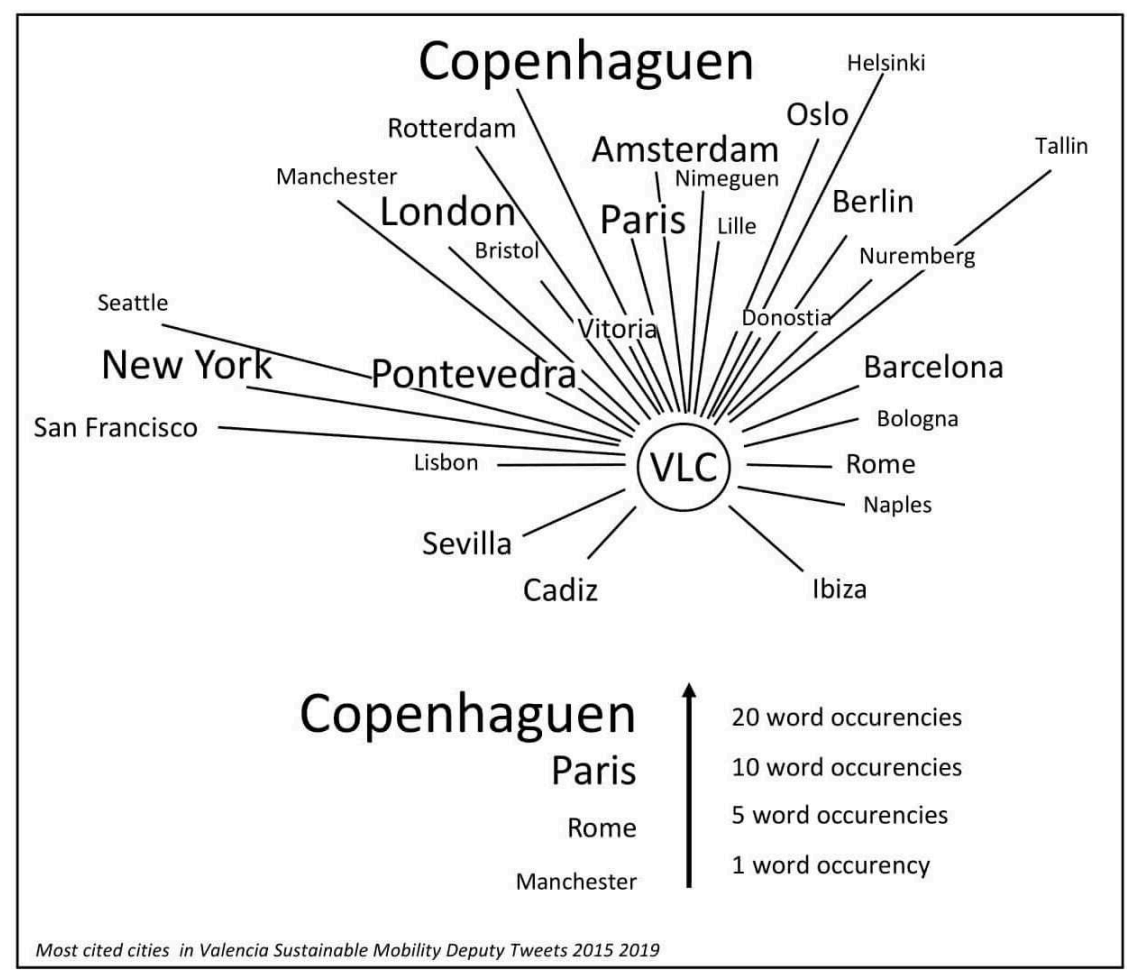

\section{Result 2: A democratic and disciplined mobility: connecting mobilities with norms}

After Scollon's introductive work on discourse analysis and the making of public policy (2012), this kind of exercise has been informed by research on examples of mobilityrelated local political communication on the part of new civil leaders in France, Germany and the UK (Vignon, 2016; Tschoerner-Budde, 2018; Kiernan, 2018). We specifically draw on research conducted by the latter, which works from Matthiessen's registerial cartography (2015) and which introduced us to the use of the round to analyse pro-bike discourses. Once again, our aim is not to present the functional linguistic approach as a whole, but to borrow this tool in order to explore "the registers that make up a langage, i.e. the adaptation of meaning resources of a language according to the context of use" (Matthiesen, 1995, p. 1). Matthiesen's round provides a typology of 8 "fields of activity": expounding, reporting, recreating, sharing, doing, enabling, recommending and exploring. This typology has been simplified to categorize the tweets into four groups, reflecting the sequences and stages of the argumentation. First moment: SHARING - Opposition associated with scandal is discredited. Second moment: REPORTING - Change is rooted and made visible in policy practices. Third moment: EXPOUNDING - Benefits of adopting the sustainable mobility model are transposed and linked with the good practices of other cities. 
Fourth moment: RECOMMENDING - Values are affirmed, change is effected, urban identity and democratic integrity are recovered.

As Twitter is a continuous conversation, the Twitter statement is rarely self-initiated but is rather a response to other people, opponents or supporters, and a direct jump into the political battle. The politician shares values and information: fake news in the local newspaper, owned by companies still connected to the former municipal majority, or true facts. This first step is a positioning discourse and makes sense for the local audience: while rectifying some facts about municipal mobility policy, it polarises local debate.

The second moment acts as the illustrative part of the argument. These tweets demonstrate that a tangible transformation is happening in the city. They concern what the municipality is actually doing for sustainable mobilities. The messages cover facts, figures, photographic evidence: the reality of the redesign of a specific street, the reality of reduced speeds calculated in situ, the exact length of bikelanes built... all factors that have a single conclusion: political change is made real by the modification of public space and the rise in bicycle use. These statements include a whole raft of messages on the politician's technical (hyper)activity: urban planning, traffic regulation, mobility education and mobility awareness. The quantity of these messages and the insistence with which they are hammered home, prove that the purpose of this political communication is less to inform than to respond to contradiction and to reinforce facts that have been inaccurately or inadequately reported by third parties (press, opposition...).

The third moment is associated with tweets that describe the effects of this policy (better health, better quality of life), its intentions (reform of behaviours, regeneration of urban design, recapture of space for pedestrians and bicycles) and the triggering of an irreversible process that will develop civility, then civism, then citizenship. This is the argumentative phase in which the impacts of sustainable mobility are emphasised. Scientists and experts are quoted. The urgency of responding to climate change and the limits of car development are presented either at micronarrative level (how Valencia's streets were converted to car traffic in the 1980s) or at macronarrative level (worldwide pollution and environmental damage).

32 The fourth moment is used to expand the normative equation: mobility civility $\rightarrow>$ urban civism $\rightarrow$ democratic citizenship. These tweets call on people, for example, to respect pedestrian space on the sidewalks and not to park in bus lanes. Civism is cited to encourage behaviours (travelling by bicycle on a peak pollution day). Citizenship relates to the recognition of human rights, which is the culmination of this political engagement, with messages that connect new mobilities and fairness, justice, solidarity and social rights. These tweets refer to urban identity and exemplarity, and the use of "RE" is omnipresent (recover, recapture, renovate, reurbanise ...). This last group of tweets links the micronarrative level (the Valencian arena) with two global transitions: in politics and in sustainability. 
Figure 4. Reframing local policies: how local actors shape a discursive space and legitimise change through mobility policy.

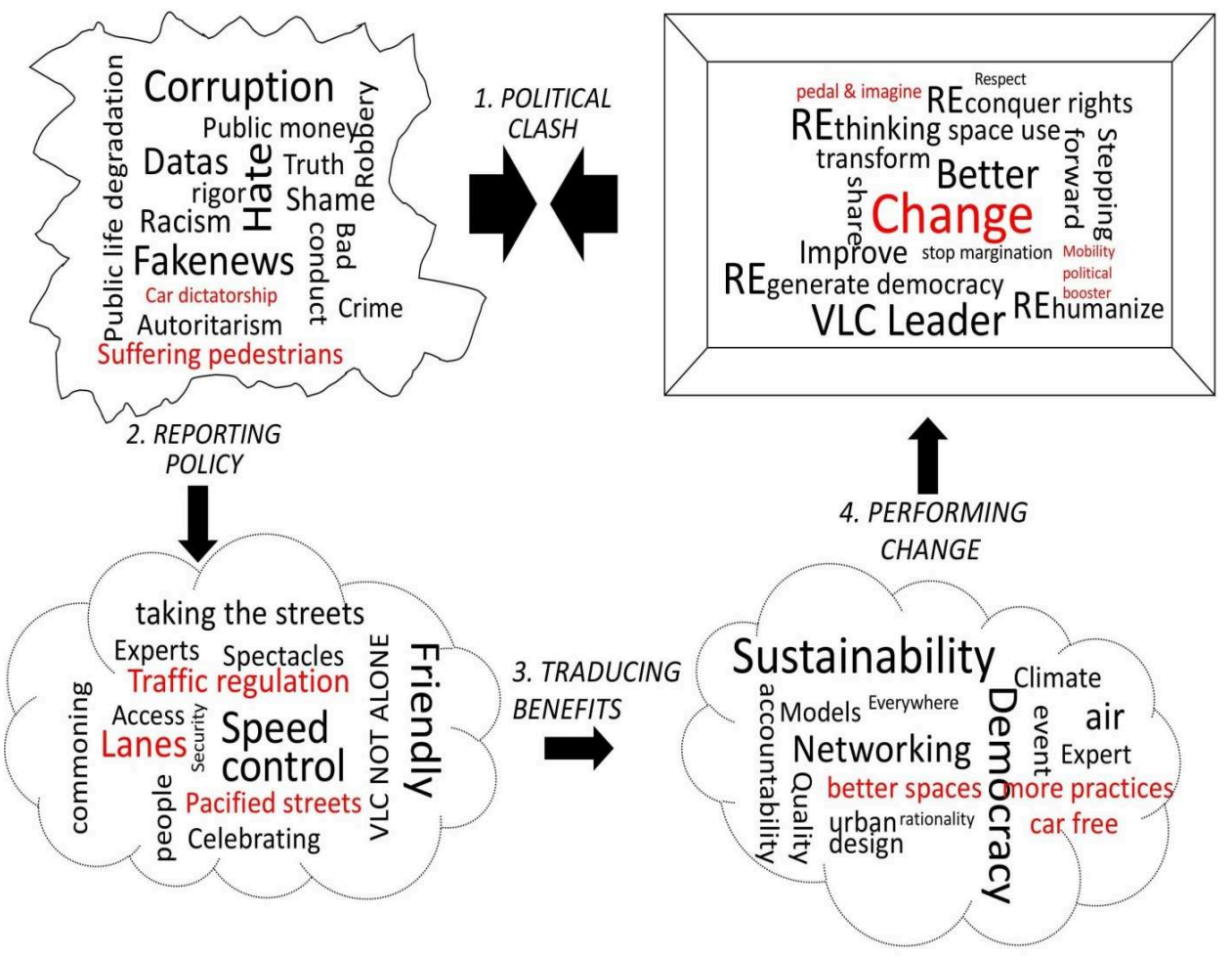

The main findings of this media discourse analysis develop the dualistic approach of McCann and Ward (2015) concerning the local fixing of sustainable policies. The strategy is to connect the former Valencia storyline (and the shame associated with the poor conduct and poor ethics of the PP) with the automobile regime. A twofold binary categorisation emerges: the contrast between before and after 2015, and the opposition between the car and sustainable mobilities. The councillor's communication polarises this discursive space through analogies and opposites. The era of the car was one of degenerate governance and public immorality. The tweets refer to Formula 1 and the fact that these politicians led the city to the highest accident rate in Spain (2013 statistics). Certain words connect ideological discourse with planning vision. Dictatorship, for example, refers either to the authoritarianism of the previous leaders (and their ideological kinship with the Franco dictatorship, since El Caudillo was honorary mayor of Valencia until 2012), or to the "dictatorship of the car" and to "suffering pedestrians". The word "conduct" sets up a contrast between the delinquent conduct that led the previous administration to prison and the relaxed conduct of cyclists who are considerate of each other. Finally, "pacification" refers both to traffic calming and the need to remake society after two decades of hate.

This strategy exacerbates the local debate. Some authors consider that Valencia has always been a heated political arena (Gonzalez and Pazos, 2015). Other broader studies on transitions in Mediterranean cities highlight the importance and specificities of local political conflict (Lorrain, 2017). This is certainly part of the background against which all these linguistic expressions, formulations and arguments need to be considered. Here, our concern is only to underline the fact that conflict is accepted. Paradoxically, traffic calming leads to political agitation. Multiple voices, even from within the municipal team, accuse the councillor for sustainable mobility not only of 
verbal excess, but of overpolitisation: he is stepping outside his proper domain, going beyond his prerogatives. He is the transgressive position of an "intermediary" who has exceeded his normal technical role in traffic planning through excessive media exposure. For what results?

\section{Is overpoliticising sustainable mobilities a mistake?}

\section{When tactical urbanism and normative discourses encounter structural mobility constraints}

A first broad conclusion of this study is that the emergence of sustainable mobilities on Valencia's political agenda has not been exempt from grandstanding and "scandalisation" strategies (Garraud, 1990). Our view is that this is partly a default strategy and can be intepreted as a result of the municipality's institutional lack of room for manoeuvre elsewhere.

Some background regarding the multilevel governance and the dynamics of the political scene at local, metropolitan, regional and national level can help explain this view. Let us start with transport responsibilities. While the Madrid and Barcelona transport systems are regulated by a metropolitan transport authority, Valencia Spain's third biggest city - had none until 2017 (Sorribes, 2017). The Valencian metro, regional/metropolitan and light rail network are thus run by the Transport Department of the Socialist-led Autonomous Community. The regional and municipal governments are political allies, but frictions regularly arise between the Socialist Party and the coalition. As a result, intermodality (the capacity to connect bicycle, bus and metro services) is absent from the tactical urban strategy and from the public discourse of the mayor and his team. The focus on bicycle mobilities and the city centre can be seen as a way to obfuscate this important problem. To move on to institutional questions, we find that, like other public services, the regional transport system is chronically underfunded because the Valencia region structurally receives much less from national gouvernment than other regions (Baron, 2014). And finally the economic context: from 2015 to the present day, municipal services remain under austerity constraints. Valencia has reinvested in its bus system, but not much in road infrastructure with the exception of the bike lanes and cycle tracks. 
Figure 5 . A cyclist is using one of the recent bikelanes developped by Valencia Municipality on a large urban road, with the Arts and Science Museum in the background.

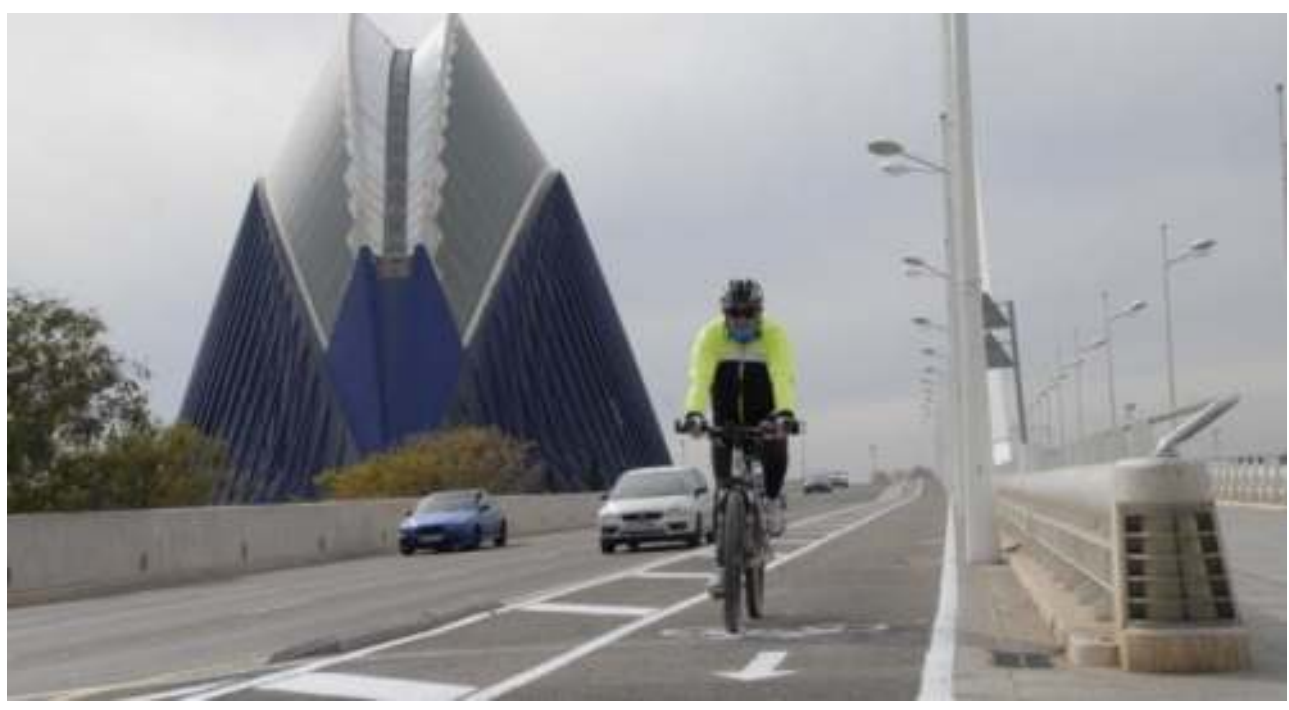

A second result of the study is that the over-politicisation of sustainable mobilities also seems to be a way to avoid tackling the structural problems of the urban and transport system, which have their roots in the urban fabric and urban morphology (see figure 5). Like other Spanish cities, neither the centre nor the outskirts are well-suited to rapid conversion to ecological modes. The urban fabric in the heart of the city remains very dense, a "monastic" structure with narrow streets and no room for wide pavements to encourage walking, to install bike parks, or to introduce separate cycle lanes. The centre is also a political trap. The municipality is working on neighbourhoods where its electoral support is weak, creating the conditions for a political discrepancy. And finally, the centre is also an ideological trap for this progressive municipality. Sustainable mobilities contribute to processes of gentrification that resemble an updated version of touristic-urban capitalism.

The peripheral areas are also a political problem with a morphological substrate. Taming the incoming arterial roads is technically difficult. In the 1970s and 80 s, these wide, straight avenues were redeveloped for the car, at a time when the city saw itself as lagging behind in the automobile revolution (Teixidor, 1980). The headlong increase in motorised travel that has occurred in the last 40 years is linked with several factors: residential sprawl, the city's status as capital of the autonomous community, the increase in through-traffic with the growth of the port and the agri-industrial expansion of the Huerta and its associated road freight (Bellver, 2018) ${ }^{7}$. Today, as the city becomes increasingly multipolar, daily commuting distances have grown (Cascajo et al., 2018) and make a majority of Valencians dependent on the car.

Socio-territorial trends also hamper the population's adoption of sustainable modes. In the absence of a housing plan, sustainable mobilities in the city centre reinforce inequalities of access (Pitarch, 2013). Tactical urbanism has nothing to say about longterm issues of housing structure. For the moment, the section of the population that lives in the city centre is not conducive to the adoption of the bicycle and pedestrian modes. The low-income and/or immigrant populations have low rates of employment, travel little within the city, and make very limited use of sustainable modes. A housing regeneration programme would have attracted students and young people working in 
the two nearby universities, a demographic change that would have been consistent with the adoption and democratisation of sustainable modes.

\section{Opening the discussion: How do sustainable mobilities "land" in Mediterranean cities?}

In this section, we interpret the Valencia findings and discuss whether they can be generalised to other cities. We consider that the Valencia case study can open a more general discussion about the patterns and pathways of sustainable mobility in southern Europe. However, caution in such a debate is of course needed because a first term of office is a short time in which to observe the transformative power of mobility policies. But the objective is not to measure the effectiveness of Valencia municipality's effort to develop cycling, but to question - here and in other contexts - the interactions between the two turning points presented in the introduction, namely the disruptive change in the electoral cycle and long-term transition in urban mobilities.

41 First, in our view, Valencia is a rare and positive example among big cities in Spain, Italy or Greece of the capacity of a municipality to fix and frame the mobility transition in local politics. Through mobilities, the coalition has succeeded in cleaning up the city's image and partially convincing the local audience and, perhaps more, the international bicycle community, of the link between local political renaissance and the local bicycle revolution. However, there are limitations to this process: internally, maintaining the political conflict between right and left at local level can lead to a "bikelash" (Wild et al., 2018). Opinion remains highly divided, even in the grassroots movements that supported the municipality in the early days. Such divisions in the progressive majority have also been observed in other Spanish municipalities of change, and even more intensely in Madrid and Barcelona. The most interesting thing, however, is that bike collectives reveal broader ideological contradictions and inconsistencies in Valencia's mobility strategy (Ortega, 2018).

Second, the Valencian case study attracts criticisms of two kinds. The first is that there is not much change in the actions of the leftist municipality, because it is implementing measures decreed by the much despised right former municipality. ${ }^{8}$ This is true, but does not apply to other Spanish cities. The second criticism is that this municipal strategy corresponds to, or at least is tied in with, other interests. It should not be forgotten that Valencia is home to a big Ford factory, which is heavily committed to smart mobility (electric cars, autonomous vehicles) (Ortega and Martinez, 2016). By eliminating internal combustion vehicles from the city, the municipality is objectively preparing Valencia to act as a showcase, introducing the prospect of bicycle policy being used as a fix, as has already been done in London (Spinney, 2016).

The third line of discussion concerns the connection between discursive "cycletopias" (Cooper and Leahy, 2017) and the territorial and cultural context of bike practice. The weakness of tactical urbanism is that it focuses too much on the question of behaviours and does little to engage with the profound cultural dimensions of urban mobility as a whole in a Mediterranean urban society (Passafaro et al., 2014). From 2015 to 2019, the Danish or Dutch experts invited to Valencia by the deputy mayor have encouraged Valencians to do more cycling and have provided many rational arguments (health, wealth, moral values). They have thought less about how to adapt cycling to the Mediterranean habitus, and about which population groups they wanted to convince 
and how. After a careful survey, a local ethnologist considers that advent of the bicycle is still, in part, perceived in Valencia as the intrusion of an external model (Ortega, 2016). However, as he concludes, and this can also be said for Portuguese, Italian, Greek or Moroccan cities, a change in mobilities will not take place without a profound reshaping of cultural attachments and collective representations.

\section{Conclusion}

This research emphasises the heuristic benefit of the Valencian case for understanding how mobilities can be used as an instrument for the transformation of space, of society and of local political models. In this city, the redefinition of mobility norms is being used to reinforce the assertive dimension of a political alternative. It is being employed to introduce a new model of public space, but also to embody a new form of political awareness and action.

Our investigation has shown the many ways in which this agenda is spatialised, and how space shapes mobility and politics. We have conceptualised the role of storylines or narratives in effecting policy change. We have described the physical capture and festive occupancy of key sectors of the city. We have then explored the argumentative stages in a political conflict and the connection of mobility norms with democratic values. We have seen how cycling identities have emerged as a fertile area for nurturing a new political identity and how mobility as a new political package is carefully framed in social media. We concluded that mobility is indeed key to the expression of local power through space and that it is used to reassert the legitimacy of politics and to rehabilitate the city's image.

This study can form the starting point for further research in the city: additional material from other media (e.g. newspaper articles) could be used to map readership, to explore the virality of mobility-related messages and to track the opposition line of counter argument (especially the defence of motorists, which is a strong local current). Aspects of this research approach should also be applied elsewhere in order to adopt a more comparative perspective: this would help in exploring links between local power entrepreneurship and mobility transition policies.

\section{BIBLIOGRAPHY}

ABELLAN LOPEZ M.A., PARDO BENEYTO G., (2017), «Las políticas públicas simbólicas para el buen gobierno y la calidad democrática en la Comunitat Valenciana», INGURUAK, Revista vasca de sociología y ciencia politica, 62, pp. 39-54.

ARENIVAR M. (2017), «El universo discursivo politico del tema de la movilidad», Letras verdes, Revista Latinoamericana de estudios socioambientales, 21, pp. 32-48. 
BARON N. (2014), « Une approche territoriale de la corruption urbaine en Espagne », in MONIER F., DARD O. \& ENGELS J.P., Patronage et corruption politiques dans l'Europe contemporaine, Armand Colin, pp. 245-260.

BARON N. (2014), «Les relations entre Etat et communautés autonomes au prisme de leurs conflits financiers et fiscaux», Séminaire : Compétences et solidarités entre Etat central et régions, Université de Lille 2, 21 février 2014.

BARON N. (2019), “Governing spanish municipalities through mobilities”, Pôle Sud, revue européenne de sciences politiques de l'Europe du sud, à paraître.

BELLVER J. (2018), «Infraestructuras, movilidad y cambio urbano : Valencia 1990-2010», Revista de obras publicas, 3062, pp. 84-87.

BOIRA MAQUES J.V. (2003), "Science, politics and image in Valencia: a review of urban discourse in the Spanish City", Cities, 20, 6, pp. 413-419.

BOIX PALOP A., MARZAL RAGA R. (2015), « Politicas de Movilidad sostenible a escala local », in BOIX PALOP A., ROMERO J., Democracia desde abajo. Nueva agenda para el gobierno local: políticas públicas, cohesión social y buen gobierno en la Comunidad Valenciana tras la reforma del régimen local, Publicaciones de la Universitat de València, pp. 305-315.

BOTELLA A., STUART K. \& GADEA L. (2015), “A journalistic corpus: a methodology for the analysis of the financial crisis in Spain", $7^{\text {th }}$ International Conference on Corpus Linguistics: Current Work in Corpus Linguistics: Procedia - Social and Behavioral Sciences, 198, pp. 42-51.

CASCAJO R., MONZON A., ROMERO C. \& RUIZ DE GALARRETA J. (2018), Observatorio movilidad metroplitana. Informe 2016, Centro de investigacion del transporte, Universidad politécnica de Madrid, $100 \mathrm{p}$.

CHIRBES R. (2009), Crematorio, Madrid, Anagrama, 424 p.

COOPER J., LEAHY T. (2017), “Cycletopia in the sticks: bicycle advocacy beyond the city limits”, Mobilities, 12, 5, pp. 611-627.

CUCO I GINER J. (coord.) (2013), La ciucad pervertida: una mirada sobre la Valencia global, Barcelona, Anthropos.

DEL ROMERO RENAU L., VALERA LOZANO A. (2016), "From Nimby to the 15 M: a decade of urban conflicts in Barcelona and Valencia”, Territory, politics, governance, 4, 3, pp. 375-395.

DIAZ PARRA I., JOVER BAEZ J. \& ROCA MARTINEZ B. (2017), « Del 15M al giro electoralista. Proyectos espaciales y fetiches políticos en las estrategias de acción colectiva », Cuadernos Geográficos, 56, 1, pp. 344-364.

ESTEBAN M., SORRIBES MONRABAL J. (2016), «Del no lugar a la ciudad vacia», in COLOMER RUBIO J.C. (coord), Valencia 1808-2015, La historia continua, 2, pp. 143-146.

FENOLL V. (2015), «Estrategias de los usuarios para controlar el dialogo en los medios digitales durante el juicio de Francisco Camps», Dígitos: Revista de Comunicación Digital, 1, pp. 179-198.

FERNANDEZ CORONADO GONZALEZ R. (2000), De la crisis a la rehabilitación de los centros históricos : la ciutat vella de Valencia, Thèse, Université de Valencia.

GARRAUD P. (1990), «Discours des maires et construction locale du politique», Mots, 25, pp. 7-21.

GARRAUD P. (2010), «Articles agenda/émergence», in BOUSSAGUET L. et al., Dictionnaire des politiques publiques, Presses de Sciences Po, coll. « Références », pp. 58 - 67. 
GONZALEZ L.R., PAZOS O.M. (2015), «Logiques urbaines et politiques de transport en Espagne: du consensus au conflit», Sud-Ouest Européen, 40, pp. 85-99.

HASSENTEUFEL P. (2010), «Les processus de mise sur agenda : sélection et construction des problèmes publics», Informations sociales, 1, 157, pp. 50-58.

HERAN F. (2014), Le retour de la bicyclette. Une histoire des déplacements urbains en Europe de 1817 à 2050, La Découverte.

KENNEDY S. (2016), "Urban policy mobilities, argumentation and the case of the model city", Urban geographies, 37, 1, pp. 96-116.

KIERNAN P. (2018), Language, Identity and Cycling in the New Media Age. Exploring Interpersonal Semiotics in Multimodal Media and Online Texts, Palgrave Macmillan.

LINDON M., GARCIA A. (2015), Tactical urbanism: short term action for long term change, Washington DC, Island Press, 256 p.

LINHEIRA J., RIUS ULLDEMOLINS J., HERNÀNDEZ I. MARTÍ G.M. (2018), «Política cultural, modelo de ciudad y grandes infraestructuras culturales: análisis comparativo de la Cidade da Cultura de Santiago de Compostela y la Ciutat de les Arts i les Ciències de Valencia», Revista de investigaciones políticas y sociológicas, 17, 1, pp. 153-178.

LONGHI J. (2016), «Le tweet politique efficace comme même textuel : du profilage à la viralité», Travaux de linguistique, 73, 2, pp. 107-126.

LOPEZ GARCIA G. (2015), «Valencia: de bastión del PP a símbolo del cambio de ciclo», in Participació electoral i territori. Anàlisi de les eleccions municipals i autonòmiques, Valencia, Publicacions de la Universitat de València, pp. 25-44.

LORRAIN D. (2017), Métropoles en Méditerranée. Gouverner par les rentes, Presses de Science Po.

LLUCH VILLAR P. (2014), «Del parlamento a la prensa: estrategias comunicativas en el caso Gürtel valenciano», Eu-topías : revista de interculturalidad, comunicación y estudios europeos, 7, pp. 5-18.

MATTHIESSEN C.M.I.M. (2015), "Register in the round: Registerial cartography”, Functional Linguistics, 2, 9, pp. 1-48.

MCCANN E., WARD K. (2015), “Thinking Through Dualisms in Urban Policy Mobilities”, International Journal of Urban and Regional Research, 39, 4, pp. 828-830.

MCCANN E., WARD K. (2012), “Assembling urbanism: following policies and studying 'through' the sites and situations of policy making”, Environment and Planning A., 44, pp. 42-51.

MEDINA M.A. (2018), «En Valencia ahora vivimos una revolución ciclista», El Pais, Blog Ilovebicis, https://elpais.com/elpais/2018/06/11/i_love_bicis/1528703149_988650.html.

MILANI MEDEIROS R., DUARTE F. (2013), "Policy to promote bicycle use or bicycle to promote politicians? Bicycles in the imagery of urban mobility in Brazil", Urban, Planning and Transport Research, 1, 1, pp. 28-39.

MOULD O. (2014), "Tactical urbanism, the new vernacular of the creative city", Geography Compass, 8 , 8, pp. 529-539.

ORTEGA BOTELLA D. (2016), Ciudadanos en pedales. Una etnografía sobre la nueva cultura de movilidad. El caso de la ciudad de Valencia, Thèse de doctorat, Université de Valence.

ORTEGA BOTELLA D. (2018), «La ciudad amable y el poder de los movimientos ciclistas», in BARON N., ROMERO J., Cultura territorial y innovacion social, Hacia un nuevo modelo metropolitano en la Europa del Sur?, Presses de l'Université de Valence, pp. 351- 368. 
ORTEGA BOTELLA D., MARTINEZ NOVO R. (2016), «Otra vuelta de tuerca. La bicicleta en Valencia y el renovado capitalismo urbano», in GRUPO DE ESTUDIOS ANTROPOLÓGICOS LA CORRALA (coord.), Cartografía de la ciudad capitalista Transformación urbana y conflicto social en el Estado Español, Traficantes de Sueños, pp. 111- 136.

PASSAFARO P., RIMANO A, PICCINI M., METASTASIO R., GAMBARDELLA V., GULLACE G. \& LETTIERI C. (2014), "The bicycle and the city: desires and emotions versus attitudes, habits and norms", Journal of environmental psychology, 38, pp. 76-83.

PITARCH GARRIDO M.D. (2013), "Measuring equity and social sustainability through accessibility to public services by public transport. The case of the metropolitan area of Valencia (Spain)", European Journal of Geography, 4, 1, pp. 64-85.

PUEYO CAMPOS A., HERNANDEZ NAVARRO M.L. (2013), «España ante la Gran Recessión del siglo XXI», Mappemonde, 3, 111, http://mappemonde.mgm.fr/num39/articles/art13301_es.html.

PRYTHERCH D. (2003), "Urban planning and a Europe transformed: the landscape politics of scale in Valencia”, Cities, 20, 6, pp.421-428.

PRYTHERCH D., DALY D.T. (2014), "Rights and Duties of Circulation on American Streets: To 'Proceed Uninterruptedly' or “with Reasonable Care'?”, Mobilities, 10, 2, pp. 211-229.

PRYTHERCH D., HUNTOON L. (2005), “Entrepreneurial regionalist planning in a rescaled Spain: The cases of Bilbao and Valencia", Geojournal, 62, pp. 41-50.

REIGNIER H. (2016), "Neoliberal Rationality and Neohygienist Morality. A Foucaldian Analysis of Safe and Sustainable Urban Transport Policies in France", Territory, Politics, Governance, DOI: 10.1080/21622671.2015.1123647.

ROMERO J., BRANDIS D. \& MELO ESCRIHUELA C. (2015), «El giro neoliberal de las politicas para la ciudad en España. Balance a partir de ejemplos de Madrid y Valencia», Boletín de la Asociación de Geógrafos Españoles, 69, pp. 369-386.

ROMERO J., SALOM CARRACO J., ALBERTOS PUEBLA J.M., PITARCH GARRIDO M.D., MELO ESCRIHUELA C. (2018a), «Trayectoria y recomposicioón metropolitana pos-crisis en Valencia : ¿a la búsqueda de nuevos modelos? ", Ciudad y Territorio, Estudios territoriales? 198, pp. 679-696.

ROMERO J., BRANDIS D., DELGADO VINAS C., GARCIA RODRIGUEZ J.L., GOMEZ ROMERO M.L., OLCINA J., RULLAN O., VERA REBOLLO J.F. \& VICENTE RUFI J. (2018 b), «Aproximación de la geografía del despilfarro en España : balance de las ultimas dos decadas», Boletín de la Asociación de geografós españoles, 77, pp. 1-51.

SANTAMARINA CAMPOS B. (2014), «La Ciudad suplantada. Percepciones sobre los nuevos imaginarios (turísticos) de la ciudad de Valencia», Pasos: Revista de Turismo y Patrimonio Cultural, 12, 4, pp. 707-718.

SANTAMARINA CAMPOS B., MONCUSI FERRE A. (2013), «De huertas y barracas a galaxias faraonicas : percepciones sociales sobre la mutacion de la ciudad de Valencia», Papers: revista de sociología, 98, 2, pp. 365-391.

SAVAGE G. (2019): “What is policy assemblage?”, Territory, Politics, Governance, https://doi.org/ 10.1080/21622671.2018.1559760.

SORRIBES MONRABAL J. (2015), Mis queridos promotores, Valencia 1940-2011: Construcción y destrucción de la ciudad, Presses de l'Université de Valence, 467 p.

SORRIBES MONRABAL J. (2017), «El area metropolitana de Valencia : del ser al deber (o poder ser)», in PITARCH GARRIDO M.D., Estructura, vida y gobierno en territorios complejos : el área metropolitana de Valencia, pp. 17-38. 
SPINNEY J. (2016), «Fixing Mobility in the Neoliberal City: Cycling Policy and Practice in London as a Mode of Political-Economic and Biopolitical Governance», Annals of the American Association of Geographers, 106, 2, pp. 450-458.

TARAZONA VENTO A. (2015), «Santiago Calatrava and the 'power of faith': global imaginaries in Valencia», International Journal of Urban and Regional Research, 39, 3, pp. 550-567.

TEIXIDOR DE OTTO M.J. (1980), «Una lectura de la expansion urbana de Valencia: el modelo de crecimiento axial», Cuadernos de geografía, 27, pp. 157-172.

TEMENOS C., NIKOLAEVA A., SCHWANEN T., CRESSWELL T., SENGERS F., WATSON M. \& SHELLER

M. (2017), "Theorizing mobility transitions: an interdisciplinary conversation", Transfers: Interdisciplinary Journal of Mobility Studies, 7, 1, pp. 113-129.

TEMENOS C., MC CANN E. (2012), “The local politics of policy mobility: learning, persuasion, and the production of a municipal sustainability fix", Environment and Planning A, 44, pp. 1389-1406.

TSCHOERNER-BUDDE C. (2018), Sustainable Mobility in Munich: Exploring the Role of Discourse in Policy Change, Springer.

TUBB D. (2014), "Narratives of citizenship in Medellin Colombia”, in ROJAS C., METZLER J., Narratives and imaginings of citizenships in Latin America, Routledge, pp. 103-116.

URRY J. (2004), “The 'System’ of automobility”, Theory, Culture Society, 21, pp. 25-39.

VELASCO PEREZ R. (2016), Comunicación política: La Comunidad Valenciana antes, durante y después de las elecciones de 2015, Master de Journalisme, Université de Valladolid, 62 p.

VESES JIMENEZ M. (2016), La quinta etapa de regeneracion del frente maritimo post-industrial, los casos de Valencia y Estocolmo, Thèse de doctorat, Université polytechnique de Valence.

VIGNON S. (2016), «Des maires en campagne(s). Transformations des répertoires de mobilisation électorale et des registres de légitimité politique dans les mondes ruraux», Politix, 1, 113, pp.

17-42.

WILD K., FIELD A. \& MACMILLAN A. (2018), “Beyond Bikelash: engaging with community opposition to cycle lanes", Mobilities, 13, 4, pp. 505-519.

\section{NOTES}

1. City with a population of 800,000 within a metropolitan area of some 1.5 million people.

2. Un barrio vivo y dynamico, pero al mismo tiempo tranquilo y attractivo, de calles limpias, con preferencia peatonal, buen oferta comercial y turismo respectuoso Interview with the head of mobilities in the El Pais newspaper, 12 January 2016, p. 41.

3. Valencia was a bastion of Spain's People's Party until 2015. The regional assembly headed it from 1995 and administered the city continuously from 1991, through Rita Barbera, a charismatic Mayor who won 6 terms in succession, 5 with an absolute majority. This Party became immersed in a series of politico-financial scandals linked with the following affairs: public contract awards in the era of the president of the Valencia Community Eduardo Zaplana (Erial case), fake invoices in the management of a theme park (terra Mítica case), hidden commissions and moneylaundering also affecting Madrid's People's Party (Gürtel case), fake jobs (Fitur case), embezzlement of public funds in the construction of a Formula 1 track (F1 case), hidden commissions to property developers (Brugal case), influence peddling, etc. Rita Barbera died before going to trial, but some one hundred representatives of the municipal majorities and regional majorities prior to 2015 were accused, and several dozen went to prison. 


\section{31 January 2016.}

5. València, ara sí, és una festa. Una festa de tots i totes. Una festa compartida, popular, oberta. Com la ciutat que somniàrem i que era comença a ser realitat (Twitter message by the head of sustainable mobilities and public space 1/1/2018).

6. "Los gobiernos locales podemos y tenemos que jugar un papel central en el combate contra las tesis de la ultraderecha : la manipulación de la información, la explotación de la desigualdad y la construcción de una identidad excluyente" (Twitter message by the head of sustainable mobilities at the time of an interview in the newspaper Publico on 14 July 2018).

7. Every day, there are 900,000 movement of cars into the city centre and 150,000 individual movements of vehicles in transit in the Valencia agglomeration (source: PMOME).

8. The idea of pedestrianising the historic city centre goes back to 1999 , and the first cycle lane plan was launched in 2013.

\section{ABSTRACTS}

This article explores the local political strategies associated with the implementation of sustainable bike policies in southern European cities. It combines geographical concepts and methods, on the one hand, and sustainable policy studies on the other hand, with the aim of highlighting the specificities of the Mediterranean political context of mobility transition. Using Valencia as a case study, it shows that tactical urbanism is being used to put sustainable mobilities on the local agenda. This justifies and embodies a change in municipal policy and politics after a decade of crisis. Sustainable mobility projects materialise and spatialise, in various ways, democratic values within public space. The article therefore studies the strategies employed to mark the urban territory with green mobility infrastructures (part 1); it reveals the construction of a discursive space that polarises local debates (part 2); it describes the symbolic reintegration of Valencia into a network of model cities (part 3). Such a strategy does not create an effective Mediterranean model of the cycle-friendly city, because it does not modify the structural organisation of space or the social representations that underpin current mobility practices (part 4).

Cet article analyse les stratégies locales associées au lancement de politiques vélos dans les villes d'Europe du sud. Il articule des concepts et méthodes de la géographie avec des travaux relevant de l'étude des politiques de la durabilité, en vue d'éclairer les spécificités de la transition mobilitaire dans le contexte méditerranéen. En s'appuyant sur le cas de Valencia, il montre que l'urbanisme tactique est utilisé pour mettre à l'agenda les mobilités durables. Ceci justifie et incarne un changement dans la manière dont la politique municipale est conçue et mise en œuvre après une décennie de crise. Les mobilités durables matérialisent et spatialisent, sous des formes variées, des valeurs démocratiques au sein de l'espace public. Par conséquent l'article étudie les stratégies utilisées pour marquer le territoire urbain avec des infrastructures (partie 1); il révèle la construction d'un espace discursif qui polarise le débat local (partie 2); il décrit la réintégration symbolique de Valencia dans un réseau de villes de référence (partie 3). Cependant une telle stratégie ne crée pas effectivement un nouveau modèle de ville méditerranéenne amie du vélo, parce qu'elle ne modifie pas encore suffisamment ni la structure urbaine, ni les représentations sociales qui sous-tendent les pratiques de déplacement habituelles. 
INDEX

Mots-clés: mobilités durables, politiques municipales, urbanisme tactique, communication politique, Valencia

Keywords: sustainable mobilities, local policy, tactical urbanism, political communication, Valencia

\section{AUTHOR}

NACIMA BARON

Université Paris Est, Laboratoire Ville Mobilité Transport UMR 9403, nacimabaron@gmail.com 